\title{
Peningkatan Kesejahteraan Ibu Hamil dengan Prenatal Yoga
}

\author{
Yuni Astuti ${ }^{1^{*}}$ dan Yusi Riwayatul Afsah ${ }^{1}$ \\ ${ }^{1}$ Universitas Muhammadiyah Yogayakarta, Jl. Brawijaya, Tamantirto, Bantul, Yogyakarta, 55183 \\ *Email: yuni.astuti@umy.ac.id
}

\begin{abstract}
Abstrak
Ibu hamil mengalami perubahan fisik dan psikologis selama proses kehamilan. Perubahan fisik yang muncul mengakibatkan ibu mengalami beberapa keluhan nyeri pada punggung bagian belakang, badan terasa lebih lemas, dan mudah lelah. Berdasarkan wawancara dengan kader kesehatan di Wilayah Gejawan wetan dan Gejawan Kulon ibu hamil sering mengeluhkan badan terasa pegal - pegal dan kaku, selain itu ibu hamil di wilayah ini belum pernah mengikuti senam selama hamil. Salah satu upaya yang dilakukan untuk mengurangi masalah tersebut yakni dengan edukasi tentang adaptasi pada ibu hamil, aktifitas selama hamil dan prenatal yoga bagi ibu hamil. Setelah mengikuti kegiatan ini diharapkan ibu hamil dapat mengatasi keluhan yang dirasakan selama hamil dengan melakukan aktifitas yang sesuai bagi ibu hamil serta melakukan senam prenatal yoga. Dengan hal ini nyeri punggung belakang yang dirasakan ibu dapat berkurang sehingga dapat meningkatkan kualitas hidup ibu hamil.
\end{abstract}

Kata kunci: Ibu hamil, Prenatal yoga, Low Back Pain (LBP)

\begin{abstract}
Pregnant women experience physical and psychological changes during the pregnancy process. Physical changes impact the mother experiencing several complaints of back pain, weakness body, and tired easily. Based on the interviews with health volunteers in the Gejawan Wetan and Gejawan Kulon region found that pregnant women complain of stiffness in the body frequently. In addition, pregnant women in this region have never participated in exercise during their pregnancy. The program to reduce this problem is giving health education about adaptation in pregnant women, activities during pregnancy and prenatal yoga for pregnant women. After participating in this program, it is expected that pregnant women can overcome their complaints during pregnancy by doing some activities which are suitable for pregnant women and doing prenatal yoga exercises as well. Therefore, with those activities, the back pain among pregnant women can be reduced so that the quality of life of pregnant women can be improved.
\end{abstract}

Keywords: Pregnant, Prenatal Yoga, Low Back Pain

Format Sitasi: Astuti, Y. \& Afsah, Y.R. (2019). Peningkatan Kesejahteraan Ibu Hamill dengan

Prenatal Yoga. Jurnal Solma, 08(1), 47-53. Doi: http://dx.doi.org/10.29405/solma.v8i1.2966

Diterima: 27 Januari 2019 | Revisi: 01 April 2019 | Dipublikasikan: 30 April 2019.

\section{PENDAHULUAN}

Kehamilan merupakan proses alami yang dialmi oleh perempuan dalam periode kehidupannya. Selama proses kehamilan terjadi perubahan pada ibu hamil. Salah satu adaptasi yang terjadi pada ibu hamil yakni pembesaran uterus (rahim) (Cuningham, et al, 2010). Pembesaran uterus selama kehamilan mengakibatkan pergeseran pusat 
gravitasi tubuh, dan perubahan postur tubuh yang dapat menyebabkan lordosis dan peningkatan lengkungan pada tulang spinal dan meningkatkan tekanan pada punggung bagian bawah (Sabino \& Grauer, 2008). Kondisi ini dapat menimbulkan keluhan pada ibu hamil yakni low back pain (LBP).

Data menunjukkan kejadian LBP pada ibu hamil ditemukan mencapai 68\% (Carvalho et al., 2017). (Ansari, Hasson, Naghdi, Keyhanis., \& Jalaie, 2010) menyampaikan sebanyak 57.3\% ibu hamil mengalami LBP. LBP merupakan nyeri yang dapat mengganggu aktifitas ibu hamil, insomnia, dan cuti bekerja pada ibu pekerja (Jimoh et al., 2013).

Pemberian farmokologi, senam, relaksasi, yoga, physiotherapy, dan massage dapat digunakan untuk mengatasi LBP pada ibu hamil (Katonis, et al, 2011). Ibu hamil yang rutin melakukan yoga prenatal dapat meningkatkan kualitas hidupnya (Curtis, Weinrib, \& Katz, 2012). Ibu hamil dapat menggunakan yoga prenatal sebagai salah satu alternatif untuk meningkatkan kualitas hidup dan mengurangi gangguan ketidaknyamanan yang dirasakan selama proses kehamilan.

Desa Balecatur, kecamatan Gamping, Sleman, Yogyakarta, dibelah oleh jalan Wates yang merupakan jalan Raya Yogyakarta menuju Jakarta. Sisi utara desa Balecatur berupa daerah datar yang subur, sedangkan di selatan berupa daerah perbukitan padas yang agak tandus. Desa Balecatur memiliki luas 931.705 Ha yang terdiri dari 18 padukuhan, dengan 54 RW dan 130 RT, dan jumlah penduduk sebanyak 16.446 yang terdiri dari 4.141 KK.

Meskipun demikian, program peningkatan kualitas hidup bagi ibu hamil di wilayah Gejawan Wetan dan Gejawan Kulon Balecatur Gamping Sleman, Yogyakarta ini belum pernah dilakukan. Selain itu, meski jumlah ibu hamil yang cukup banyak di wilayah ini, namun belum ada kegiatan kelas hamil dengan prenatal yoga untuk meningkatkan kesejahteraan ibu hamil.

\section{MASALAH}

Berdasarkan hasil wawancara yang dilakukan oleh tim kepada salah satu anggota ranting aisyiyah Balecatur selama ini ibu hamil yang memiliki gangguan kenyamanan selama kehamilan hanya mendapatkan senam hamil. Belum ada pelatihan prenatal yoga yang diberikan pada ibu hamil. Selama ini, ibu hamil jarang mengatasi ketidaknyamanan yang muncul selama kehamilan. Ketidaknyamanan yang dirasakan hanya diatasi dengan 
istirahat sehingga dapat muncul kembali. Apabila ketidaknyamanan tersebut tidak teratasi maka ibu hamil berkunjung ke Puskesmas untuk memperoleh obat.

\section{METODE PELAKSANAAN}

Metode pelaksanaan dalam kegiatan ini dilakukan dalam tiga tahapan yakni tahap perencanaan, tahap pelaksanaan, dan tahap evaluasi.

\section{Tahap Perencanaan}

Pada tahap ini yang dilakukan pertama yakni mengajukan permohonan ijin dengan kantor Kelurahan Balecatur, Sleman, berkoordinasi dengan kader kesehatan di desa Gejawan Wetan dan Gejawan Kulon, selain itu pada tahap ini tim juga menyiapkan media edukasi berupa buku saku dan menyiapkan peralatan.

2. Tahap Pelaksanaan

Kegiatan pengabdian masyarakat ini dilakasanakan dalam dua kali kegiatan. Kegiatan pertama berupa penyuluhan tentang adaptasi atau perubahan - perubahan yang terjadi selama kehamilan, edukasi prenatal yoga, dan praktek prenatal yoga bagi ibu hamil. Kegiatan kedua berisi edukasi tentang aktivitas selama hamil, dan praktek prenatal yoga.

3. Tahap Evaluasi

Tahap terakhir yakni evaluasi. Tahap ini digunakan untuk mengevaluasi perencanaan dan pelaksanaan dari program pengabdian masyarakat yang telah diberikan kepada ibu hamil. Evaluasi kegiatan dengan melihat pretest dan post-test dari kualitas hidup, skor LBP, dan testimoni dari ibu hamil yang mengikuti PKM. Evaluasi kualitas hidup ibu hamil menggunakan kuesioner kualitas hidup (WHOQOL-BRIEF) yang terdiri dari 4 dimensi yakni fisik, psikologis, social, dan lingkungan. Nyeri punggung belakang atau LBP dievaluasi menggunakan visual analog scale (VAS). Evaluasi yang dilakukan untuk melihat apakah program yang diberikan dapat mengurangi keluhan - keluhan yang dirasakan oleh ibu selama hamil.

\section{PEMBAHASAN}

Program pengabdian masyarakat ini bertujuan untuk meningkatkan kemampuan ibu hamil dalam mengurangi keluhan yang muncul selama kehamilan melalui peningkatan pemahaman tentang adaptasi yang terjadi selama kehamilan, dan aktivitas yang dapat dilakukan perempuan selama kehamilan serta peningkatan kemampuan ibu hamil dalam melakuan senam prenatal yoga untuk mengurangi keluhan yang dirasakan. 
Hasil yang diperoleh setelah mengikuti program ini semua ibu hamil tetap memiliki kualitas hidup yang baik. Kualitas hidup merupakan persepsi ibu hamil terhadap dirinya yang berkaitan dengan fisik, psikologis, sosial dan lingkungan. Ibu hamil yang memiliki kualitas hidup baik dapat meningkatkan perannya dan meningkatkan kesejahteraan dirinya (World Health Organization, 1996). Kualitas hidup yang baik mampu meningkatkan kesejahteraan ibu hamil. Ibu hamil yang melakukan aktifitas fisik memiliki kualitas hidup yang lebih baik (Lagadec et al., 2018). Menurut Handy Satria Yudha, (2014) ibu hamil yang mengalami hambatan aktivitas sosial dipengaruhi oleh faktor fisik.

Keluhan yang sering dialami oleh ibu selama proses kehamilan yakni low back pain (LBP). Perkembangan janin membuat uterus semakin membesar dan semakin menekan pada daerah - daerah disekitar uterus (Pillitary, et al, 2010). Hal ini mengakibatkan kompresi pada tulang belakang, tekanan semakin meningkat dibanding pada perempuan yang tidak hamil (Rodacki, Fowler, Rodacki, \& Birch, 2003).

Prevalensi kejadian LBP pada ibu hamil mencapai 72\% (Sabino \& Grauer, 2008), terdapat $106(34,3 \%)$ ibu hamil yang berkunjung saat pemeriksaan kehamilan mengalami LBP (Usman, Abubakar, Muhammad, Rabiu, \& Garba, 2017). Selain itu menurut Khan et al., (2017) menyampaikan bahwa sebanyak 68,8\% ibu hamil trimester ketiga mengalami LBP. Kejadian LBP pada ibu hamil meningkat berdasarkan usia kehamilan, kejadian LBP pada trimester kedua lebih tinggi dibandingkan trimester ketiga (Carvalho et al., 2017).

LBP pada ibu hamil dalam kegiatan ini diukur menggunakan VAS yang diukur sebelum dan setelah dilakukan kegiatan. Hasilnya ditampilkan dalam tabel dibawah ini.

Tabel 1. Evaluasi tingkat nyeri punggung belakang (Low back pain) antara sebelum dan sesudah diberikan edukasi dan yoga prenatal

\begin{tabular}{|c|c|c|c|c|c|c|c|}
\hline \multirow{2}{*}{ No } & Variabel & \multicolumn{3}{|c|}{ Sebelum } & \multicolumn{3}{c|}{ Sesudah } \\
\cline { 3 - 8 } & & Ringan & Sedang & Berat & Ringan & Sedang & Berat \\
\hline 1 & Tingkat nyeri & - & $70 \%$ & $30 \%$ & 100 & - & - \\
\hline
\end{tabular}

Hasil pada tabel diatas menunjukkan bahwa semua ibu hamil mengalami nyeri punggung bawah dengan kriteria nyeri sedang. (Ansari et al., 2010) menyampaikan bahwa sebagin besar ibu hamil mengalami LBP dengan $71.2 \%$ nyeri dirasakan pada punggung bawah. Setelah mengikuti prenatal yoga menunjukkan penurunan skala nyeri. Hal ini membuktikan bahwa latihan senam yoga prenatal yang diberikan dapat memberikan pengaruh dalam penurunan keluhan LBP yang dirasakan ibu hamil selama masa kehamilan. Latihan senam yoga prenatal ini sangat bermanfaat terutama untuk 
meningkatkan kenyamanan pada ibu dalam menjalani masa kehamilan, sehingga kesejahteraan kesehatan ibu dan janin akan meningkat. Menurut Kumar, Harish, Harsha, \& Dhanesh Kumar, (2016) menyampaikan bahwa yoga yang dilakukan saat hamil mampu menurunkan nyeri LBP yang dirasakan, meningkatkan aktivitas sehari - hari serta meningkatkan kesehatan fisik dan mental menjadi lebih baik.

Hasil wawancara dengan ibu hamil yang mengikuti senam prenatal yoga menunjukkan jika sebelumnya mereka sering merasakan badan pegal - pegal, sering kesemutan, dan nyeri pada bagian punggung. Setelah mengikuti kegiatan semua ibu hamil menyampaikan bahwa merasakan perubahan yakni badan terasa segar, ringan, kesemutan berkurang, dan ringan saat melakukan aktifitas. Senam prenatal yoga yang dilakukan rutin dapat membantu mengurangi keluhan ketidaknyamanan yang dialami oleh ibu hamil. Menurut Kumar et al., (2016) terdapat perbedaan yang signifikan antara ibu hamil yang mendapatkan yoga hamil dengan yang tidak melakukan senam yoga hamil terhadap nyeri LBP dan disabilitas saat hamil. Senam yoga hamil yang menyatukan mind-body dapat meningkatkan kesehatan, mengurangi stress dan meningkatkan kesadaran diri bagi ibu hamil (Curtis et al., 2012).

Pelaksanaan pengabdian masyarakat senam yoga prenatal terdapat beberapa kesulitan seperti kesulitan saat sesi relaksasi karena terdapat suara yang mengganggu sehingga peserta tidak bisa fokus, namun kendala tersebut dapat diatasi dengan memindahkan lokasi kegiatan diruang tertutup sehingga bukan menjadi kendala yang berarti saat pertemuan kedua dilakukan.

\section{KESIMPULAN}

Kegiatan ini mampu meningkatkan kemampuan ibu hamil dalam melakukan senam prenatal yoga hamil. Ibu hamil yang mengikuti kegiatan dapat melakukan praktek mandiri senam prenatal yoga dirumah, sehingga semua peserta mampu menurunkan nyeri dari $L B P$ yang dialami menjadi skala ringan. Program ini baik jika dapat diterapkan pada ibu hamil lainnya, dengan mengambil area yang lebih luas.

\section{UCAPAN TERIMA KASIH}

Terimakasih kepada LP3M (Lembaga Penelitian Publikasi dan Pengabdian Masyarakat) Universitas Muhammadiyah Yogyakarta sebagai pemberi dana kegiatan Pelatihan dan terimakasih kami ucapkan kepada Kelurahan Balecatur Gamping Sleman 
Yogyakarta, Kader kesehatan wilayah Gejawan Wetan dan Gejawan Kulon sebagai mitra dan membantu proses program peningkatan kesejahteraan bagi ibu hamil.

\section{DAFTAR PUSTAKA}

Ansari, N. H., Hasson, S., Naghdi, S., Keyhanis., \& Jalaie, S. (2010). Low back pain during pregnancy in Iranian women: Prevalence and risk factors. Physiother Theory Pract., 1(26), 40-48. https://doi.org/10.3109/09593980802664968

Carvalho, M. E. C. C., Lima, L. C., de Lira Terceiro, C. A., Pinto, D. R. L., Silva, M. N., Cozer, G. A., \& Couceiro, T. C. de M. (2017). Low back pain during pregnancy. Brazilian Journal of Anesthesiology, 67(3), 266-270. https://doi.org/10.1016/j.bjan.2016.03.002

Curtis, K., Weinrib, A., \& Katz, J. (2012). Systematic review of yoga for pregnant women: Current status and future directions. Evidence-Based Complementary and Alternative Medicine, 2012(June 2014). https://doi.org/10.1155/2012/715942

Handy Satria Yudha. (2014). Gambaran Health-Related Quality of Life Pada Ibu Hamil Di Yogyakarta. Konferensi Nasional II Psikologi Kesehatan, Psikologi Universitas YARSI 21-22 Juni 2014, At Jakarta, Indonesia, Volume: Jilid 1, (March), 2-15. https://doi.org/10.13140/RG.2.1.2450.4480

Jimoh, A. A. G., Omokanye, L. O., Salaudeen, A. G., Saidu, R., Saka, M. J., \& Akinwale, A. (2013). Medical Practice and Review Prevalence of low back pain among pregnant women in Ilorin , Nigeria. 4(April), 23-26. https://doi.org/10.5897/JDOH12.014

Khan, M. J., Israr, A., Basharat, I., Shoukat, A., Mushtaq, N., \& Farooq, H. (2017). Prevalence of Pregnancy Related Low Back Pain in Third Trimester and Its Impact on Quality of Life and Physical Limitation. 12(1), 39-43.

Kumar, P., Harish, B. N., Harsha, S. ${ }^{3}$ dr, \& Dhanesh Kumar, B. ${ }^{4}$ dr. (2016). IJPHY EFFICACY OF YOGA ON LOW BACK PAIN \&amp; DISABILITY IN PRIMI GRAVIDAS. Int $J$ Physiother Int $J$ Physiother. Int $J$ Physiother, 3(32), 182-185. https://doi.org/10.15621/ijphy/2016/v3i2/94882

Lagadec, N., Steinecker, M., Kapassi, A., Magnier, A. M., Chastang, J., Robert, S., ... Ibanez, G. (2018). Factors influencing the quality of life of pregnant women: a systematic review. BMC Pregnancy and Childbirth, 18(1), 455. https://doi.org/10.1186/s12884-018-2087-4

Rodacki, C. L., Fowler, N. E., Rodacki, A. L., \& Birch, K. (2003). Stature loss and recovery in pregnant women with and without low back pain. Archives of Physical Medicine and Rehabilitation, 84(4), 507-512. https://doi.org/10.1053/apmr.2003.50119

Sabino, J., \& Grauer, J. N. (2008). Pregnancy and low back pain. Current Reviews in Musculoskeletal Medicine, 1(2), 137-141. https://doi.org/10.1007/s12178-008-9021-8 
Usman, M., Abubakar, M., Muhammad, S., Rabiu, A., \& Garba, I. (2017). Low back pain in pregnant women attending antenatal clinic: The Aminu Kano teaching hospital experience. Annals of African Medicine, 3(16). https://doi.org/https://doi.org/10.4103/aam.aam_214_16

World Health Organization, W. (1996). WHOQOL-BREF: Introduction, administration, scoring, and generic version of the assessment.

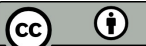

(C) 2019 Oleh authors. Lisensi Jurnal Solma, LPPM-Uhamka, Jakarta. Artikel ini bersifat open access yang didistribusikan di bawah syarat dan ketentuan Creative Commons Attribution (CC BY) license. (http://creativecommons.org/licenses/by/4.0/). 